\title{
THE CHAGOS MARINE PROTECTED AREA ARBITRATION: EXPANSION OF THE JURISDICTION OF UNCLOS PART XV COURTS AND TRIBUNALS
}

\author{
Stefan TALMON*
}

\begin{abstract}
This article shows that the Tribunal in the Chagos Marine Protected Area Arbitration between Mauritius and the United Kingdom has contributed considerably to the creeping expansion of compulsory jurisdiction of courts and tribunals established under Part XV of the United Nations Convention on the Law of the Sea (UNCLOS). The Tribunal has employed three techniques to do so. First, it has read down the jurisdictional precondition to exchange views in Article 283(1) of the UNCLOS; second, it has expanded the limited scope of compulsory subject-matter jurisdiction under section 2 of Part XV by broadening the meaning of the phrase 'any dispute concerning the interpretation or application of this Convention' to include incidental, related-and through the backdoor of a balancing exercise-even extraneous disputes; and, third, it has restricted the limitations and exceptions to compulsory jurisdiction in Articles 297 and 298 of the UNCLOS. Few would have predicted in 1982 that a Part XV court or tribunal would - within the context of such a balancing exercise - ever find that a colonial era undertaking created binding legal obligations under international law and that the United Kingdom was obliged to return the Chagos Archipelago to Mauritius when no longer needed for defence purposes. The Tribunal's expansive reading of the jurisdictional provisions in Part XV opens up the possibility of future rulings, albeit incidentally, on issues that have little to do with the law of the sea.
\end{abstract}

Keywords: Chagos Marine Protected Area Arbitration, compulsory jurisdiction, dispute settlement, law of the sea, UNCLOS Part XV courts and tribunals.

\section{INTRODUCTION}

On 18 March 2015, a Tribunal constituted under Annex VII of the United Nations Convention on the Law of the Sea (UNCLOS or the Convention) rendered its Award in the matter of the Chagos Marine Protected Area Arbitration between Mauritius and the United Kingdom (the Chagos MPA Arbitration). ${ }^{1}$ The arbitration concerned the

* Professor Stefan Talmon is Director of the Institute for Public International Law at the University of Bonn and Supernumerary Fellow of St. Anne's College, Oxford. He practises as a barrister from 20 Essex Street Chambers, London, talmon@jura.uni-bonn.de.

1 The Award and all other case documents referred to are available at $<$ http://www.pcacases. com/web/view/11>. 
establishment by the United Kingdom in April 2010 of a Marine Protected Area (MPA) in the waters surrounding the Chagos Archipelago. Prior to 1965, the Chagos Archipelago had been administered as a dependency of the then British colony of Mauritius. On 8 November 1965, the Archipelago was detached from the colony to be administered separately by the United Kingdom as the British Indian Ocean Territory. At the time, the United Kingdom made certain undertakings (the 1965 Lancaster House Undertakings) to secure the consent of Mauritian political leaders to the detachment. The United Kingdom undertook, inter alia, to ensure that fishing rights remained available to Mauritians in the waters surrounding the Chagos Archipelago, to return the Archipelago to Mauritius when no longer needed for defence purposes and to preserve for Mauritius the benefit of any minerals or oil discovered in or near the Archipelago pending its eventual return. Mauritius became independent on $12 \mathrm{March}$ 1968; since at least 1980 it has asserted that the detachment of the Chagos Archipelago was unlawful and that it has sovereignty over the archipelago. The United Kingdom has rejected these claims.

On 1 April 2010, the United Kingdom established the MPA, including a no-take fishing zone, around the Chagos Archipelago following limited discussion of the subject in bilateral talks with Mauritius. Mauritius commenced arbitration proceedings on 1 December 2010 under Part XV of the UNCLOS claiming, inter alia, that the United Kingdom was not entitled to declare the MPA because an MPA could only be declared by the 'coastal State' and the United Kingdom was not the 'coastal State' for the purposes of the Convention. Alternatively, Mauritius submitted that the United Kingdom had endowed Mauritius with the relevant rights as a 'coastal State' in respect of the Archipelago. Independently of the 'coastal State' issue, Mauritius claimed that the MPA was incompatible with the United Kingdom's substantive and procedural obligations under the Convention and the 1995 Agreement for the Implementation of the Provisions of the United Nations Convention on the Law of the Sea Relating to the Conservation and Management of Straddling Fish Stocks and Highly Migratory Fish Stocks (1995 Fish Stocks Agreement). ${ }^{2}$

The Tribunal found, by a narrow majority of three votes to two ${ }^{3}$ that it lacked jurisdiction to consider Mauritius' claim that the United Kingdom was not the 'coastal State' in respect of the Chagos Archipelago and its claim that the United Kingdom had endowed Mauritius with rights as a 'coastal State' in respect of the Archipelago. The majority determined that the dispute between the Parties expressed through these claims did not concern the interpretation or application of UNCLOS but, in fact, concerned the question of sovereignty over the Chagos Archipelago. The Tribunal, however, unanimously found that it had jurisdiction to consider Mauritius' claim that the establishment of the MPA surrounding the Chagos Archipelago was incompatible with the United Kingdom's obligations under the Convention. It held that in establishing the MPA, the United Kingdom breached its procedural obligations under

2 Agreement for the Implementation of the Provisions of the United Nations Convention on the Law of the Sea of 10 December 1982 Relating to the Conservation and Management of Straddling Fish Stocks and Highly Migratory Fish Stocks (adopted 4 August 1995, entered into force 11 December 2001) 2167 UNTS 88.

3 The majority of the Tribunal consisted of Professor Ivan Shearer (President) and Judges Sir Christopher Greenwood and Albert Hoffmann. Judges James Kateka and Rüdiger Wolfrum concurred in part and dissented in part with the decision reached by the majority and attached a joint Dissenting and Concurring Opinion to the Award. 
Articles 2(3), 56(2) and 194(4) of the $\mathrm{UNCLOS}^{4}$ to consult and give due regard to the legally binding rights of Mauritius under the 1965 Lancaster House Undertakings.

The paper examines the Tribunal's decision on the scope of compulsory jurisdiction of courts and tribunals under Part XV of UNCLOS. The compulsory jurisdiction of Part XV courts and tribunals is not unlimited. The Annex VII Tribunal in the Southern Bluefin Tuna Arbitration rightly observed that 'UNCLOS falls significantly short of establishing a truly comprehensive regime of compulsory jurisdiction entailing binding decisions'. ${ }^{5}$ Claimant parties have, time and again, tried to push the boundaries of compulsory jurisdiction under UNCLOS Part XV due to the lack of other avenues of compulsory jurisdiction. In the Chagos MPA Arbitration Mauritius tried to entice the Tribunal to take jurisdiction over a classic sovereignty dispute by re-characterizing it as a 'who is the coastal State' dispute. Counsel for Mauritius stated:

If a Part XV tribunal does not have jurisdiction to interpret the words 'coastal State', there is a great deal over which it will not have jurisdiction. It is hard to see how dispute settlement could be said to be effective. To so decide would, in effect, be to cut off the legs of Part XV dispute settlement. We ... conclude, and invite you to so conclude, that you have jurisdiction to decide this issue. ... The skies will not fall if you so rule. ${ }^{6}$

Counsel also argued that by taking jurisdiction over the case the Tribunal would 'strengthen the dispute settlement structure of the Convention'; declining jurisdiction would be to 'exacerbate the dispute, to prolong it unnecessarily'. ${ }^{7}$ In other words, assuming jurisdiction would make the world a better place. ${ }^{8}$ The fact that the 'coastal State' claim was rejected only by a three to two majority shows that some arbitrators are susceptible to an expansive reading of the provisions on compulsory jurisdiction in UNCLOS Part XV. While the Award in the Chagos MPA Arbitration has mainly been noted, and welcomed, for the majority's decline of jurisdiction over territorial sovereignty disputes, ${ }^{9}$ it has largely gone unnoticed that not only the two dissenting judges (the minority) but also the three arbitrators forming the majority (the majority) have considerably expanded the compulsory jurisdiction of Part XV courts and tribunals.

Dispute settlement in UNCLOS Part XV is organized in three sections. Compulsory dispute settlement is set out in section 2, which is sandwiched between the procedural preconditions of compulsory settlement in section 1 (ie the steps that must be taken before the mandatory procedures in section 2 can be utilized) and the limitations and exceptions to compulsory settlement in section 3. This organization opens up several ways to expand the compulsory jurisdiction of Part XV courts and tribunals. First, the procedural preconditions of compulsory jurisdiction in section 1 can be read down; second, the limited scope of compulsory subject-matter jurisdiction under section 2 can be expanded by broadening the meaning of 'any dispute concerning the

${ }^{4}$ Unless otherwise stated article references are to the Articles of the UNCLOS.

5 Southern Bluefin Tuna (New Zealand-Japan, Australia-Japan) (Jurisdiction and Admissibility, Award of 4 August 2000) 23 RIAA 45, para 62.

${ }^{6}$ Chagos MPA Arbitration, Hearing on Jurisdiction and the Merits, Final Transcript, 1030: 4-14 (Philippe Sands).

7 ibid, 430: 16-18 (Philippe Sands). $\quad{ }^{8}$ ibid, 648: 22-23 (United Kingdom).

9 See eg DA Colson and BJ Vohrer, 'In re Chagos Marine Protected Area (Mauritius v United Kingdom)' (2015) 109 AJIL 851; LN Nguyen, 'The Chagos Marine Protected Area Arbitration: Has the Scope of LOSC Compulsory Jurisdiction Been Clarified?' (2016) 31 International Journal of Marine and Coastal Law 124-35. 
interpretation or application of this Convention'; and, third, the limitations and exceptions to compulsory jurisdiction in section 3 can be restricted. As will be shown, the arbitrators in the Chagos MPA Arbitration have effectively employed all three techniques.

\section{READING DOWN THE PROCEDURAL PRECONDITIONS OF COMPULSORY JURISDICTION}

The first means to expand the compulsory jurisdiction of UNCLOS Part XV courts and tribunals is to read down or interpret restrictively the procedural preconditions of compulsory jurisdiction in section 1 of Part XV. For example, before the compulsory dispute settlement procedures in section 2 can be invoked, the threshold jurisdictional requirement in Article 283(1) must be fulfilled. If a party fails to meet this requirement a Part XV court or tribunal will have to find that it lacks jurisdiction to hear the case. The provision provides that:

When a dispute arises between States Parties concerning the interpretation or application of this Convention, the parties to the dispute shall proceed expeditiously to an exchange of views regarding its settlement by negotiation or other peaceful means.

The obligation to exchange views has frequently been invoked by parties before UNCLOS Part XV courts and tribunals. ${ }^{10}$ The purpose of Article 283(1) is to ensure that States are not taken entirely by surprise by the initiation of compulsory dispute settlement procedures and to allow States to rectify any possible wrongdoing or violation of the Convention prior to the initiation of binding dispute settlement procedures. ${ }^{11}$

The Tribunal made important pronouncements on the content, form and length of the exchange of views required under Article 283(1). It found that the provision lays down a procedural and not a substantive requirement. To fill this requirement, the parties must 'exchange views regarding the means for resolving their dispute'; they need not in fact 'negotiate the substance of the dispute'. ${ }^{12}$ In other words, the parties must exchange views on the conditions for negotiations, rather than engage in actual negotiations. Article 283(1) is thus a provision particular to the Convention and distinct from any requirement that parties engage in substantive negotiations prior to resorting to compulsory dispute settlement. To the extent that a requirement to engage in substantive negotiations before resorting to compulsory settlement could be considered to be implied from the structure of sections 1 and 2 of Part XV, discussion of the issue during bilateral talks and in diplomatic correspondence would suffice. ${ }^{13}$

10 See generally, D Anderson, 'Article 283 of the United Nations Convention on the Law of the Sea' in TM Ndiaye and R Wolfrum (eds), Law of the Sea, Environmental Law and Settlement of Disputes: Liber Amicorum Judge Thomas A Mensah (Brill 2007) 847.

11 cf Chagos MPA Arbitration, Award, paras 381, 382.

12 ibid, para 378. See also ibid, 383 and Dissenting and Concurring Opinion, para 66. The prior jurisprudence of the ITLOS in provisional measures proceedings might have given the impression that what is required under art 283 is an exchange of views on the substance of the parties' dispute; see Arbitration between the Republic of the Philippines and the People's Republic of China (South China Sea Arbitration), Hearing on Jurisdiction and Admissibility, Day 2, 8 July 2015, 25-26. But see also The Arctic Sunrise Arbitration (Netherlands v Russian Federation) (Merits, Award of 14 August 2015) para 151.

${ }^{13}$ cf Chagos MPA Arbitration, Award, para 379. 
In its exchange of views with another State Party a State is not obliged to refer expressly to the UNCLOS, much less to any specific provision of the Convention. ${ }^{14}$ Article 283 only requires that a dispute has arisen with sufficient clarity that the parties are aware of the issues in respect of which they disagree. ${ }^{15}$ It thus suffices that the exchange of views refers to the subject-matter of the UNCLOS so that the State against which a claim is made can identify that there is, or may be, a dispute with regard to that subject-matter. ${ }^{16}$ Article 283 does not require that 'the exchange of views include the possibility of compulsory settlement or that - before resorting to compulsory settlement - one party caution the other regarding the possibility of litigation or set out the specific claims that it might choose to advance'. ${ }^{17}$

Article 283(1) is to be applied by courts and tribunals 'without an undue formalism as to the manner and precision with which views were exchanged and understood' ${ }^{18}$ The Tribunal observed that:

[a]n overly formalistic approach does not accord with how diplomatic negotiations are carried out ... In practice, substantive negotiations concerning the parties' dispute are not neatly separated from exchanges of views on the preferred means of settling a dispute. ${ }^{19}$

The fact that correspondence or discussions between the parties 'also dealt with substantive matters' does not preclude a finding that the parties exchanged views with regard to the means to settle the dispute. ${ }^{20}$

An exchange of views does not require lengthy exchanges. ${ }^{21}$ In particular, it 'is not necessary for the parties to comprehensively canvass the means for the peaceful settlement of disputes set out in either the United Nations Charter or the Convention'. ${ }^{22}$ The applicant State's subjective judgment as to when to terminate the exchange of views is accorded considerable respect. In this respect, the Tribunal followed the International Tribunal for the Law of the Sea (ITLOS) holding that a State is not 'obliged to continue with an exchange of views when it concludes that the possibilities of reaching agreement have been exhausted' ${ }^{23}$

The requirement of an exchange of views, as developed in the case law of ITLOS and UNCLOS Annex VII arbitral tribunals, has always been a jurisdictional hurdle of very

14 cf ibid, para 379 and Dissenting and Concurring Opinion, paras 63, 64.

15 cf Chagos MPA Arbitration, Award, para 382. See also South China Sea Arbitration (Jurisdiction and Admissibility, Award of 29 October 2015) para 333.

${ }^{16} \mathrm{cf}$ ibid, para 379; referring to Application of the International Convention on the Elimination of All Forms of Racial Discrimination (Georgia v Russian Federation) (Preliminary Objections: Judgment) [2011] ICJ Rep 85, para 30. $\quad{ }^{17}$ Chagos MPA Arbitration, Award, para 385.

18 ibid, para 382 .

19 ibid, para 381; referring to Arbitration between Barbados and the Republic of Trinidad and Tobago, relating to the delimitation of the exclusive economic zone and the continental shelf between them (Decision of 11 April 2006) 27 RIAA 206-207, paras 201-205.

${ }^{20}$ Chagos MPA Arbitration, Award, para 379. See also South China Sea Arbitration (Jurisdiction and Admissibility, Award of 29 October 2015) paras 332, 334.

21 Both parties seem to have been in agreement on this point; cf ibid, paras 359,360 .

22 ibid, para 385.

23 ibid. On the ITLOS jurisprudence, see Land Reclamation in and around the Straits of Johor (Malaysia $v$ Singapore) (Provisional Measures, Order of 8 October 2003) ITLOS Reports 2003, 20, para 47; MOX Plant (Ireland v United Kingdom) (Provisional Measures, Order of 3 December 2001) ITLOS Reports 2001, 107, para 60. 
modest height. ${ }^{24}$ With its restrictive reading of Article 283(1), the Tribunal has lowered the hurdle even further. ${ }^{25}$ Against this background, it seems highly unlikely that the provision will ever act as a procedural bar to the compulsory dispute settlement procedures in section 2 of Part XV of the UNCLOS.

\section{EXPANDING THE LIMITED SCOPE OF COMPULSORY SUBJECT-MATTER JURISDICTION}

The compulsory subject-matter jurisdiction of courts and tribunals acting under Part XV of the UNCLOS is not unlimited. ${ }^{26}$ By becoming a party to the UNCLOS, States have not undertaken to submit all disputes connected in any way to the Convention to the compulsory procedures set out in Part XV. According to Article 288(1), Part XV courts and tribunals have jurisdiction over 'any dispute concerning the interpretation or application of this Convention'. Although this provision is broadly phrased, it contains an important limitation: the dispute must concern 'the interpretation or application of this Convention'. ${ }^{27}$ The second way to expand the compulsory jurisdiction of UNCLOS Part XV courts and tribunals is thus to broaden the meaning of the phrase 'any dispute concerning the interpretation or application of this Convention'.

\section{A. The (Re-)Characterization of the Dispute}

The subject-matter jurisdiction of a Part XV court or tribunal hinges on the characterization of the parties' dispute, ie, on whether the issues raised in the submissions represent a dispute 'concerning the interpretation or application of this Convention'. ${ }^{28}$ It is for a Part XV court or tribunal itself to characterize the dispute dividing the parties and, in the process, to isolate the real issue in the case and to identify the object of the claim. ${ }^{29}$ The characterization or re-characterization of a dispute outside the Convention as a dispute concerning the interpretation or

24 See eg Southern Bluefin Tuna (New Zealand-Japan, Australia-Japan) (Request for Provisional Measures, Order of 27 August 1999) ITLOS Reports 1999, 294-295, paras 57-60; Southern Bluefin Tuna (New Zealand-Japan, Australia-Japan) (Jurisdiction and Admissibility, Award of 4 August 2000) 23 RIAA 42-43, para 55; MOX Plant (Ireland $v$ United Kingdom) (Provisional Measures, Order of 3 December 2001) ITLOS Reports 2001, 107, paras 56-60; Land Reclamation in and around the Straits of Johor (Malaysia v Singapore) (Provisional Measures, Order of 8 October 2003) ITLOS Reports 2003, 18-20, paras 33-48; Maritime Delimitation (Guyana v Suriname) (Jurisdiction and Merits, Award of 17 September 2007) (2008) 47 ILM 224-225, paras 407-410; Arbitration between Barbados and the Republic of Trinidad and Tobago, relating to the delimitation of the exclusive economic zone and the continental shelf between them (Decision of 11 April 2006) 27 RIAA 206-207, paras 201-203.

25 See also Nguyen (n 9) 142.

26 See also S Oda, 'Dispute Settlement Prospects in the Law of the Sea' (1995) 44 ICLQ 863; K Schmalenbach, 'Dispute Settlement' in J Klabbers and $\AA$ Wallendahl (eds), Research Handbook on the Law of International Organizations (Edward Elgar Publishing 2011) 253.

27 cf Chagos MPA Arbitration, Dissenting and Concurring Opinion, para 23. See also ibid, para 29. See further ibid, Hearing on Jurisdiction and the Merits, Final Transcript, 654: 3-5 (United Kingdom).

28 cf Chagos MPA Arbitration, Award, para 283.

29 ibid, para 208; referring to Fisheries Jurisdiction (Spain v Canada) (Jurisdiction of the Court: Judgment) [1998] ICJ Rep 448, para 30; Nuclear Tests (New Zealand v France) (Judgment) [1974] ICJ Rep 466, para 30. See Chagos MPA Arbitration, Award, paras 211-213, 285 and ibid, Dissenting and Concurring Opinion, paras 4, 6. 
application of the Convention thus provides the first gateway for expanding the scope of compulsory subject-matter jurisdiction. In the Chagos MPA Arbitration the Tribunal was faced with the question of whether the dispute concerned the interpretation or application of the term 'coastal State' in the Convention, ${ }^{30}$ or whether it concerned the issue of territorial sovereignty over the Chagos Archipelago. The characterization of the dispute as one or the other was decisive for the Tribunal's jurisdiction because it is widely agreed that long-standing disputes over territorial sovereignty as such do not qualify as disputes concerning the interpretation or application of the Convention. ${ }^{31}$ The UNCLOS has nothing to say about territorial sovereignty; it contains no rules on the modes of acquisition and loss of sovereignty over land territory. These questions are governed by customary international law and specific treaties. ${ }^{32}$

For the purpose of characterizing the parties' dispute, a Part XV court or tribunal 'must evaluate where the relative weight of the dispute lies'. ${ }^{33}$ Is the dispute primarily a matter of interpretation or application of a term of the Convention, with the issue of sovereignty over land territory just forming one aspect of the larger Convention question, or does the dispute primarily concern territorial sovereignty, with the interpretation or application of a term of the Convention merely representing a manifestation of that larger sovereignty dispute? ${ }^{34}$ While particular attention is to be given to the formulation of the dispute chosen by the applicant, ${ }^{35}$ this is not the only criterion to be employed to determine where the relative weight of the dispute lies. The majority in the Chagos MPA Arbitration held:

In carrying out this task, the Tribunal does not consider that its role is limited to parsing the precise wording chosen by [the applicant] in formulating its submission. On the contrary, the Tribunal is entitled, and indeed obliged, to consider the context of the submission and the manner in which it has been presented in order to establish the dispute actually separating the Parties. ${ }^{36}$

In addition to the context of the submission and the manner in which it was presented, the majority also took into consideration the historical dispute between the parties and the consequences of the requested finding. ${ }^{37}$

While Part XV courts and tribunals are supposed to characterize the dispute dividing the parties 'on an objective basis', ${ }^{38}$ the characterization of a dispute is not a scientific exercise with only one correct answer. On the contrary, any evaluation of where the

30 See eg UNCLOS, arts 2, 5-7, 14, 16, 19, 21, 22, 24, 25, 27, 28, 30, 31, 33, 56, 58-65, 67, 6971, 73, 75-82, 84, 85, 111, 116, 142, 208, 210, 211, 216, 218, 220, 234, 245-249, 252-254, 265. According to Mauritius, 'there are at least 64 uses of the term "coastal State" in the Convention' (Chagos MPA Arbitration, Hearing on Jurisdiction and the Merits, Final Transcript, 1007: 22-23).

31 cf Chagos MPA Arbitration, Award, paras 215-218. The two dissenting judges also did not consider that disputes over territorial sovereignty per se were disputes concerning the interpretation or application of the Convention but, instead, took the view that the dispute could not be qualified as a dispute about territorial sovereignty; see ibid, Dissenting and Concurring Opinion, para 9.

32 cf Chagos MPA Arbitration, Hearing on Jurisdiction and the Merits, Final Transcript, 654: 16-18, 21-23 (United Kingdom).

${ }^{33}$ Chagos MPA Arbitration, Award, para 211. See also ibid, para 229.

34 cf ibid, para $211 . \quad 36$ ibid, para 229.

37 cfibid, para 211. The United Kingdom had pointed out that 'if the sovereignty issue is decided in [Mauritius'] favour, there is nothing left; there is no residual, let alone any substantial, UNCLOS claim' (ibid, Hearing on Jurisdiction and the Merits, Final Transcript, 501: 4-5).

38 Chagos MPA Arbitration, Award, para 208. 
'relative weight' of a dispute lies is an inherently subjective exercise. In the Chagos MPA Arbitration, the majority held that the Parties' dispute 'is properly characterized as relating to land sovereignty' and that their 'differing views on the "coastal State" for the purposes of the Convention are simply one aspect of this larger dispute'. ${ }^{39}$ The majority therefore ruled that it lacked jurisdiction to consider Mauritius' claim that the United Kingdom was not the 'coastal State'. The minority, on the other hand, found that 'the dispute cannot be qualified as a dispute about the sovereignty' over land territory. ${ }^{40}$ For the minority, the situation presented itself 'exactly the other way round'. The differing views of the parties on the term 'coastal State' in the Convention were the dispute before the Tribunal and the issue of sovereignty was merely an element in the reasoning. ${ }^{41}$

Unlike the majority, the minority focused mainly on the 'wording' of the applicant's submissions. The minority found, inter alia, that the claim that, for the purposes of the Convention, the United Kingdom was not the 'coastal State' and, for that reason, could not establish an MPA around the Chagos Archipelago, was not a claim concerning the territorial sovereignty of the United Kingdom over the islands. Instead the minority found that the claim only covered an aspect thereof: namely, the establishment of the MPA. Territorial sovereignty encompassed more than the establishment of an MPA. ${ }^{42}$ For example, the applicant had not advanced any argument concerning the exercise of territorial sovereignty over the islands themselves. ${ }^{43}$ The minority pointed to the 'limited scope' of the submissions, which did not allow the Tribunal to decide the question of territorial sovereignty as such. ${ }^{44}$ Consequently, the minority assumed jurisdiction over the Convention claim that the United Kingdom was not the 'coastal State' and, incidentally, the question of sovereignty over the Chagos Archipelago.

\section{B. The Inclusion of Incidental Disputes}

Courts and tribunals under Part XV 'have some level of incidental jurisdiction'. ${ }^{45}$ As disputes concerning issues of sovereignty over land territory are not inherently beyond the jurisdiction of Part XV courts or tribunals, ${ }^{46}$ the question arises whether and, if so, under what conditions, territorial sovereignty disputes may be incidental to disputes that are, at their core, disputes concerning the interpretation or application of the Convention.

For the majority, the real issue in the case and the object of the claim did not relate to the interpretation or application of the Convention and therefore the question of incidental jurisdiction over territorial sovereignty disputes did not arise. The majority simply observed that 'an incidental connection between the [non-Convention] dispute and some matter regulated by the Convention is insufficient to bring the dispute, as a whole, within the ambit of Article 288(1)' ${ }^{47}$ Nevertheless, in two obiter dicta the

39 ibid, para 212. See also, ibid, para 229.

40 Chagos MPA Arbitration, Dissenting and Concurring Opinion, para 9.

41 ibid, paras 6, 17. As to the distinction between dispute and reasoning, see also ibid, para 42.
42 ibid, para 10.
43 ibid, para 13.
44 ibid, para 14.

45 Chagos MPA Arbitration, Hearing on Bifurcation, 11 January 2013, Final Transcript, 139: 11-13 (James Crawford for Mauritius). See also Maritime Delimitation (Guyana v Suriname) (Jurisdiction and Merits, Award of 17 September 2007) (2008) 47 ILM 225, paras 410, 441-452. See further P Tzeng, 'Supplemental Jurisdiction under UNCLOS' (2016) 38 HousJIntlL 499.

46 cf Chagos MPA Arbitration, Award, paras 213-221; ibid, Dissenting and Concurring Opinion, paras 38-45. See also Nguyen (n 9) 132.

47 Chagos MPA Arbitration, Award, para 220. See also ibid, para 213. 
majority left open the possibility of jurisdiction over some territorial sovereignty disputes incidental to disputes concerning the interpretation or application of the Convention. The majority observed:

As a general matter, the Tribunal concludes that, where a dispute concerns the interpretation or application of the Convention, the jurisdiction of a court or tribunal pursuant to Article 288(1) extends to making such findings of fact or ancillary determinations of law as are necessary to resolve the dispute presented to it....

The Tribunal does not categorically exclude that in some instances a minor issue of territorial sovereignty could indeed be ancillary to a dispute concerning the interpretation or application of the Convention. That, however, is not this case, and the Tribunal therefore has no need to rule upon the issue. ${ }^{48}$

This raises two questions: First, how is one to distinguish between 'major' and 'minor' issues of territorial sovereignty, ${ }^{49}$ and, second, what is meant by 'ancillary' to a dispute concerning the interpretation or application of the Convention. ${ }^{50}$

The minority regarded the dispute as one concerning the interpretation of the term 'coastal State' in the Convention. ${ }^{51}$ This raised the question of incidental jurisdiction over territorial sovereignty disputes. ${ }^{52}$ The minority was 'sympathetic' to Mauritius' reasoning that the meaning of the words 'coastal State' and the issues of sovereignty 'are interwoven'. ${ }^{53}$ In such a situation, they considered it 'permissible to decide incidentally about sovereignty issues', 54 if a 'genuine link' or a 'nexus' existed between a territorial sovereignty dispute and a dispute concerning the interpretation or application of any provision of the Convention, ie if the one formed 'a necessary part' of the other. ${ }^{55}$

The concepts of 'genuine link' or 'nexus' are as poorly defined and equally vague as the terms 'minor issues' or 'ancillary' employed by the majority. The same applies to the term 'incidental'. ${ }^{56}$ The minority, however, went much further than the majority: it found

48 ibid, paras 220, 221 (emphasis added).

49 See AC Neumann, 'Sovereignty Disputes under UNCLOS: Some Thoughts and Remarks on the Chagos Marine Protected Area Dispute' (Cambridge Journal of International and Comparative Law Online, 7 August 2015) <http://cjicl.org.uk/>. $\quad{ }_{50}$ See also the text at nn 126, 127 below.

51 Chagos MPA Arbitration, Dissenting and Concurring Opinion, para 45.

52 Mauritius had argued that "issues "closely linked or ancillary" to questions arising directly under the Convention are also questions "concern[ing] the interpretation or application of the Convention"'. (Chagos MPA Arbitration, Hearing on Jurisdiction and the Merits, Final Transcript, 446: 2-4). See also ibid, Memorial of the Republic of Mauritius, vol I, 1 August 2012, para 5.26.

53 Chagos MPA Arbitration, Dissenting and Concurring Opinion, para 8. $\quad{ }^{54}$ ibid, para 45.

55 ibid, paras $28,44,45$. See also the Netherlands' argument that 'the violations of the relevant rules of the law of the sea are reasonably related to violations of human rights under customary international law and the ICCPR' so that these violations would come within the compulsory jurisdiction of a Part XV tribunal; see The Arctic Sunrise Arbitration (Kingdom of the Netherlands $v$ Russian Federation) (Memorial of the Kingdom of the Netherlands, 31 August 2014) para 131 (emphasis added) <http://www.pcacases.com/web/sendAttach/1406>.

56 cf the statement of Christopher Greenwood on behalf of Guyana: 'Now, there is also the question of what is exactly meant by an incidental jurisdiction [to determine questions of territorial sovereignty] or perhaps what are the limits of an incidental jurisdiction. You have to determine a maritime boundary, one little island with just a couple of palm trees, how about two islands? What about a whole archipelago. Does it matter whether they are inhabited or uninhabited?' (Maritime Delimitation (Guyana v Suriname), Hearing Day 5, 13 December 2006, 798: 22-25 and 799: 1-2<https://www.pcacases.com/web/sendAttach/895>). 
that a mere 'incidental connection' was a sufficient basis to support the jurisdiction of Part XV courts and tribunals not just over minor issues of territorial sovereignty but also over territorial sovereignty disputes in general. Considering the overwhelming significance that States ascribe to questions of territorial sovereignty, it seems doubtful that disputes concerning sovereignty over continental or insular land territory can ever be 'ancillary' or 'incidental' to a dispute concerning the interpretation or application of the UNCLOS. ${ }^{57}$ In this connection it should also be recalled that any dispute concerning the interpretation or application of Articles 15, 74 and 83 relating to sea boundary delimitations, or any dispute involving historic bays or titles, that 'necessarily involves the concurrent consideration' of any territorial sovereignty dispute is automatically excluded from compulsory conciliation. ${ }^{58}$ It is difficult to comprehend why territorial sovereignty disputes that are inevitably and inextricably linked to specific Convention disputes should be excluded from compulsory conciliation if, at the same time, these very same sovereignty disputes could 'incidentally' be the subject of compulsory arbitration..$^{59}$

\section{The Incorporation by Reference of Related Disputes}

The subject-matter jurisdiction of UNCLOS Part XV courts and tribunals is not limited to disputes 'concerning the interpretation or application of this Convention' but, according to Article 288(2), extends to 'any dispute concerning the interpretation or application of an international agreement related to the purposes of this Convention, which is submitted to it in accordance with the agreement'. A precondition for this additional subject-matter jurisdiction is that the agreement in question expressly refers such disputes to the Part XV courts or tribunals. There are currently ten multilateral and several bilateral agreements that confer any dispute concerning their interpretation or application to the Part XV compulsory dispute settlement procedures. ${ }^{60}$

The Tribunal in the Chagos MPA Arbitration expanded the subject-matter jurisdiction of Part XV courts and tribunals further to include disputes concerning the interpretation or application of international agreements that do not expressly refer to the UNCLOS

\footnotetext{
57 See also BH Oxman, 'The United Nations Conference on the Law of the Sea: The Ninth Session (1980)' (1981) 75 AJIL 233 n 109.

${ }^{58}$ See UNCLOS, art 298(1)(a)(i).

59 But see the statement on behalf of the United Kingdom that in 'a maritime delimitation case ... an issue of identifying the precise terminus of a land boundary may arise in truly incidental fashion' (Chagos MPA Arbitration, Hearing on Jurisdiction and the Merits, Final Transcript, 501: 7-8). The question of whether an Annex VII tribunal could decide on the 'unresolved status of the land boundary terminus' when determining a maritime boundary was raised but not decided in Maritime Delimitation (Guyana v Suriname) (Jurisdiction and Merits, Award of 17 September 2007) (2008) 47 ILM 187, para 168 and 208, para 308. Suriname objected to the tribunal assuming jurisdiction over questions of territorial sovereignty in the context of a maritime delimitation dispute; see ibid, (Republic of Suriname, Preliminary Objections, Memorandum, 23 May 2005) paras 4.11-14 <https://www.pcacases.com/web/sendAttach/1195>. Guyana had argued that the Tribunal can exercise 'incidental or ancillary or other jurisdiction over territorial matters'; see ibid, Hearing, Day 1, 7 December 2006, 50: 17-18; 72: 24-25; 128: 3-4. But see also Suriname's response, ibid, Hearing Day 5, 13 December 2006, 637: 8-19; 797: 13-25 and 798: $1-15$.

${ }^{60}$ See ITLOS, 'Relevant Provisions of International Agreements Conferring Jurisdiction on the Tribunal' <https://www.itlos.org/>. See also P Gautier, 'The Settlement of Disputes' in D Attard et al. (eds), The IMLI Manual on International Maritime Law (OUP 2014) vol I: The Law of the Sea, $571-3$.
} 
Part XV compulsory dispute settlement procedures. It stated that by providing for an express renvoi to 'other rules of international law' or the 'rights of other States' (including those with a basis outside the Convention), the Convention incorporates by reference these rules and rights and thus brings any dispute concerning these rules and rights within the Tribunal's jurisdiction over disputes concerning the interpretation or application of the Convention. ${ }^{61}$ The Tribunal stated with regard to the renvoi to international agreements in Article 297(1):

Article 297(1) expands the jurisdiction of a Tribunal over the enumerated cases beyond that which would follow from the application of Article 288(1) alone... Article 297(1) includes a renvoi to sources of law beyond the Convention itself:

(a) Article 297(1)(a) establishes jurisdiction 'in regard to other internationally lawful uses of the sea specified in article 58' and Article 58, in turn, provides that 'other pertinent rules of international law' apply to the conduct of third States in the exclusive economic zone.

(b) Article 297(1)(b) establishes jurisdiction over the exercise of freedoms, rights, and uses of the sea 'in contravention of ... the laws and regulations adopted by the coastal State in conformity with this Convention and other rules of international law not incompatible with this Convention'.

(c) Article 297(1)(c) establishes jurisdiction over acts 'in contravention of specified international rules and standards for the protection and preservation of the marine environment', including those established 'through a competent international organization or diplomatic conference'.

Article 297(1) thus expressly expands the Tribunal's jurisdiction to certain disputes involving the contravention of legal instruments beyond the four corners of the Convention itself and ensures that such disputes will not be dismissed as being insufficiently related to the interpretation and application of the Convention. ${ }^{62}$

For example, the reference in Article 297(1)(c) to 'specified international rules and standards for the protection and preservation of the marine environment which have been established ... through a competent international organization or diplomatic conference' incorporates not only the rules on marine pollution control but also the rules on the protection and preservation of rare or fragile ecosystems as well as the habitat of depleted, threatened or endangered species and other forms of marine life. ${ }^{63}$ It therefore extends the jurisdiction of Part XV courts and tribunals, inter alia, to disputes relating to the contravention of the rules and standards elaborated in the MARPOL, SOLAS and London Dumping Conventions and in the relevant IMO and IAEA codes and guidelines. ${ }^{64}$

A further textual renvoi to sources of law outside the Convention can be found in Article 2(3), which provides that the 'sovereignty over the territorial sea is exercised subject to ...

61 cf Chagos MPA Arbitration, Award, paras 268, 323(a), 323(b).

62 ibid, para 316 (emphasis added).

63 cf ibid, para 320. It has been suggested that art 297(1)(c) could even be construed to include a renvoi to the Convention on Biological Diversity, the Convention on International Trade in Endangered Species and the 1995 Fish Stocks Agreement; see South China Sea Arbitration, Hearing on Jurisdiction and Admissibility, Day 2, 8 July 2015, 107: 1-4.

64 cf ibid, para 321. To this may be added the COLREGS Convention; see South China Sea Arbitration, Hearing on Jurisdiction and Admissibility, Day 2, 8 July 2015, 107: 10-12. 
other rules of international law'. ${ }^{65}$ The Tribunal found that the provision establishes an obligation of the coastal State to comply with 'other rules of international law' when exercising sovereignty over the territorial sea. ${ }^{66}$ The extent of jurisdiction of a Part XV court or tribunal over disputes concerning the contravention of these obligations thus depends on the meaning of 'other rules of international law'. The majority held that the phrase 'other rules of international law' refers only to 'the general rules of international law' such as abuse of rights and the law of State responsibility. It does not refer to 'particular rights in the territorial sea by virtue of bilateral agreements or local custom'. ${ }^{67}$ The renvoi thus does not lead to any substantive expansion of jurisdiction. Again, the minority went a step further by holding that:

$[\mathrm{T}]$ he reference to 'other rules of international law' encompasses obligations arising from commitments by the coastal State bilaterally or even unilaterally, as well as commitments based upon customary international law or the binding decisions of an international organization. ${ }^{68}$

According to the minority, these obligations 'have to be read directly into Article 2(3) of the Convention'. ${ }^{69}$ As a consequence, the minority found that disputes concerning fishing or other (resource) rights in the territorial sea based on treaties, unilateral undertakings or historic rights are subject to the compulsory jurisdiction of Part XV courts and tribunals.

The restrictive reading of the phrase 'other rules of international law' in Article 2(3) by the majority is solely based on a passage in the International Law Commission's 1956 Commentary on its Draft Articles concerning the Law of the Sea. ${ }^{70}$ As the two dissenting arbitrators have correctly pointed out, the legislative history of the provision may also be read differently. ${ }^{71}$ The last word on the scope of the renvoi in Article 2(3) and, consequently, the scope of the subject-matter jurisdiction of Part XV courts and tribunals may thus not have been spoken. In any case, a restrictive reading of the scope of a renvoi in the Convention may not always be possible, as the examples in Article 297(1) show. In addition, the references to 'other rules of international law' in Article $31,{ }^{72}$ or to a State's 'treaty obligations' in Article 116(a) do not seem to lend themselves to such a restrictive reading. ${ }^{73}$

65 The Tribunal held that any interpretation it may reach regarding the scope of obligation embodied in art 2(3) would equally apply to art 87(1). Reference was also made in this context to art 34(2) to which the same interpretation would apply; see ibid, para 503.

66 cf ibid, paras 502, 504, 514

67 ibid, para 516.

68 Chagos MPA Arbitration, Dissenting and Concurring Opinion, para 94. See also ibid, Written Observations Submitted by the Republic of Mauritius on the Question of Bifurcation, 21 November 2012, para 76.

69 Chagos MPA Arbitration, Dissenting and Concurring Opinion, para 94.

70 See Chagos MPA Arbitration, Award, paras 515-516.

71 See Chagos MPA Arbitration, Dissenting and Concurring Opinion, paras 92-94. For a different interpretation of art 2(3), see also ibid, Reply of the Republic of Mauritius, vol I, 18 November 2013, para 6.15.

72 UNCLOS, art 31 provides: 'The flag State shall bear international responsibility for any loss or damage to the coastal State resulting from the non-compliance by a warship or other government ship operated for non-commercial purposes with ... other rules of international law.'

73 UNCLOS, art 116(a) reads: 'All States have the right for their nationals to engage in fishing on the high seas subject to ... their treaty obligations.' 


\section{The Indirect Ruling on Extraneous Disputes through a 'Balancing Exercise'}

The Tribunal in the Chagos MPA Arbitration indirectly opened up the jurisdiction of Part $\mathrm{XV}$ courts and tribunals to disputes concerning the interpretation or application of sources of law beyond the UNCLOS. It did so by identifying a number of provisions in the Convention that require the balancing of rights of a State under the Convention with the legal rights and interests of other States as they otherwise arise as a matter of international law. The majority found that Article 2(3) establishes an obligation of the coastal State to comply with 'the general rules of international law' when exercising sovereignty over the territorial sea. ${ }^{74}$ It identified the obligation 'to act in good faith' with respect to the treaty and customary rights of other States in the territorial sea as one of these general rules of international law that were incorporated by reference into the Convention. ${ }^{75}$ The majority observed that the obligation to 'act in good faith' with respect to the rights of other States in the territorial sea under Article 2(3) and the obligation to 'have due regard' to the rights and interests of other States in the exclusive economic zone (EEZ) in Article 56(2) 'are, for all intents and purposes, equivalent' ${ }^{76}$ The majority held that these obligations entail, 'at least, both consultation and a balancing exercise with its own rights and interests' ${ }^{77}$ The other State had to be 'consulted in a timely manner and provided with information', ${ }^{78}$ and the State's own rights and interests and those of the other State had to be consciously balanced..$^{79}$ The majority also identified an obligation to consult and balance in Article 194(4). It held that the obligation to 'refrain from unjustifiable interference with activities carried out by other States in the exercise of their rights' requires - like the obligation to have due regard in Article 2(3) and the obligation to act in good faith in Article 56(2) - 'a balancing act between competing rights, based upon an evaluation of the extent of the interference, the availability of alternatives, and the importance of the rights and policies at issue'. ${ }^{80}$

For such a 'balancing exercise' to be properly conducted it is essential that the State takes into account all the rights and interests of the other States and pursues consultations with them. Proper balancing entails suggestions of compromise and willingness to offer assurances and an understanding of the concerns of the other State. ${ }^{81}$ To decide whether the obligations of consultation and balancing under the Convention have been complied with, Part XV courts and tribunals must necessarily rule on the existence, nature and content of these legal rights and interests that have a source outside the Convention. Any dispute concerning the interpretation or application of the sources of these rights and interests thus comes - at least indirectly - within their jurisdiction. In this respect, the dispositif of the Award is revealing. It provides in the relevant part:

74 See Chagos MPA Arbitration, Award, para 516.

75 cf ibid, para 517. The majority in fact 'invented' a customary international law obligation of the coastal State to consult with any State that may potentially have rights or interests in its territorial sea and balance those rights and interests with its own rights.

76 ibid, para 520. $\quad 77$ ibid, para 534. $\quad 7_{78}$ ibid, para 529. See also ibid, para 534.

79 cf ibid, paras 531, 535.

80 ibid, para 540. The majority held that art 194(4) 'applies only to the "activities carried out by other States" pursuant to their rights, rather than to the rights themselves' (ibid). Where rights may exist but are not exercised there is, consequently, also no obligation to consult and balance.

81 cf ibid, paras 534, 535. 
B. In relation to the merits of the Parties' dispute, the Tribunal, having found, inter alia,

(1) that the United Kingdom's undertaking to ensure that fishing rights in the Chagos Archipelago would remain available to Mauritius as far as practicable is legally binding insofar as it relates to the territorial sea;

(2) that the United Kingdom's undertaking to return the Chagos Archipelago to Mauritius when no longer needed for defence purposes is legally binding; and

(3) that the United Kingdom's undertaking to preserve the benefit of any minerals or oil discovered in or near the Chagos Archipelago for Mauritius is legally binding;

DECLARES, unanimously, that in establishing the MPA surrounding the Chagos Archipelago the United Kingdom breached its obligations under Articles 2(3), 56(2), and 194(4) of the Convention. ${ }^{82}$

The Tribunal could not 'declare' that the United Kingdom had breached Mauritius' fishing and other rights in the territorial sea and EEZ of the Chagos Archipelago originating in the 1965 Lancaster House Undertakings because it had no jurisdiction to rule on these Undertakings. According to Article 288(2), a dispute 'concerning the interpretation or application of an international agreement related to the purposes of this Convention' is only subject to the jurisdiction of a Part XV court or tribunal if that dispute 'is submitted to it in accordance with the agreement'. There was neither a provision in the Lancaster House Undertakings to submit disputes concerning their interpretation or application to a Part XV court or tribunal, nor were those Undertakings in any way related to the purposes of the UNCLOS. ${ }^{83}$ This, however, did not prevent the Tribunal from 'finding' that Mauritius possessed legally binding fishing and other rights in the territorial sea and the EEZ of the Chagos Archipelago on the basis of these Undertakings. ${ }^{84}$ The Tribunal declared that the United Kingdom breached its obligations under Articles 2(3), 56(2) and 194(4) of the Convention, not because it interfered with Mauritius' fishing and other rights but because it violated its obligation to balance its own rights with these competing rights.

In the context of this procedural balancing obligation, the Tribunal decided, albeit indirectly, on the existence, content and scope of substantive rights and obligations that originate in sources beyond the Convention. In so doing, it circumvented the jurisdictional requirements of Article 288(2). The Convention knows of numerous obligations to have 'due regard to the rights and duties' of other States, ${ }^{85}$ and is replete with references to 'other rules of international law' that can be the source of such balancing obligations. ${ }^{86}$ There is thus ample room for further expansion of the subject-matter jurisdiction of Part XV courts and tribunals through the back door of a balancing exercise.

82 ibid, para 547.

83 See also W Qu, 'The Issue of Jurisdiction Over Mixed Disputes in the Chagos Marine Protection Area Arbitration and Beyond' (2016) 47 Ocean Development \& International Law 40, who points out that "the real issue in the case was the dispute concerning the "Lancaster House Undertakings", over which the Tribunal had no jurisdiction'.

${ }^{84}$ See eg ibid, para 455: 'Mauritius enjoyed rights to fish in the waters of the Chagos Archipelago - in particular in the territorial sea'. See also ibid, paras 323, 448.

${ }_{85}$ See eg UNCLOS, arts 56(2), 58(3), 60(3), 142(1) and 267.

${ }^{86}$ See eg ibid, arts 19(1), 21(1), 24(2), 58(2), 87(1), 138 and 297(19(b)). 


\section{RESTRICTING THE LIMITATIONS AND EXCEPTIONS TO COMPULSORY JURISDICTION}

The compulsory jurisdiction of UNCLOS courts and tribunals over 'any dispute concerning the interpretation or application of this Convention' under section 2 of Part $\mathrm{XV}$ is subject to the limitations and exceptions set out in section 3 of that Part. Within section 3, Article 297 provides for a series of limitations to compulsory jurisdiction with regard to certain subject matters that apply automatically (automatic limitations), while Article 298 permits States to declare that they do not accept the compulsory settlement procedures provided for in section 2 with regard to certain additional subject matters (optional exceptions). ${ }^{87}$ The third option to expand the compulsory jurisdiction of Part $\mathrm{XV}$ courts and tribunals is thus to restrict the limitations and exceptions to compulsory jurisdiction in section 3 .

\section{A. The Characterization and Separation of Multifaceted Disputes}

One way of restricting the limitations and exceptions to jurisdiction, or at least their effect, is to characterize the dispute in such a way so that it does not come within any of the exclusions set out in section $3 .^{88}$ For example, if the establishment of an MPA is characterized as a measure relating to the 'sovereign rights [of a coastal State] with respect to the living resources in the EEZ' it will fall under the automatic limitation to jurisdiction in Article 297(3)(a). If, however, it is classed as a means for 'the protection and preservation of the marine environment' it is, according to Article 297(1)(c), subject to compulsory jurisdiction. The minority simply removed the dispute concerning the establishment of the MPA from the limitation to jurisdiction in Article 297(3)(a) by declaring 'a decision on an MPA' to be a measure for the 'protection of the biodiversity [which] does not come under the sovereign rights concerning the protection and management of living resources. It is a matter of the protection of the environment' ${ }^{89}$ But, as the majority observed, measures such as the establishment of an MPA will usually serve multiple objectives. ${ }^{90}$ This raises the question of whether a distinction can be made between the different aspects of a dispute or whether the aspects are so intertwined that they cannot be separated. The majority accepted, in principle, that multifaceted disputes can be separated..$^{91}$ It held that the different aspects of a dispute concerning both the protection and preservation of the marine environment and the conservation and management of living resources have to be treated separately. The automatic limitations to jurisdiction provided by Article 297(3)(a) for disputes concerning the coastal State's sovereign rights with respect to living resources cannot be superimposed on disputes relating to the protection and preservation of the marine environment. As a consequence, the limitation to jurisdiction under Article 297(3)(a) has to be examined with regard to each UNCLOS provision invoked by the applicant. To the extent that a provision pertains to the living resources in the EEZ, it is excluded from compulsory jurisdiction; to the extent that a provision pertains to the

87 cf Chagos MPA Arbitration, Award, para 205. See also ibid, paras 206, 216 and ibid, Dissenting and Concurring Opinion, para 29. For the terminology, see also Maritime Delimitation (Guyana $v$ Suriname) (Jurisdiction and Merits, Award of 17 September 2007) (2008) 47 ILM 225, para 413.

88 cf Chagos MPA Arbitration, Dissenting and Concurring Opinion, para 50.

89 ibid, para 56. $\quad{ }_{90}$ cf Chagos MPA Arbitration, Award, para 304.

91 cf ibid, para 304. But see also ibid, 297. 
protection and preservation of the marine environment, it is subject to compulsory jurisdiction. This led the Tribunal to conclude that in a dispute concerning the establishment of an MPA, the limitation to jurisdiction in Article 297(3)(a) applied to claims based on a violation of Articles 63 and 64 and Article 7 of the 1995 Fish Stocks Agreement, but not to claims based on Article 194. ${ }^{92}$

\section{B. The New Interpretation of Article 297(1) as a 'Jurisdiction-Affirming' Provision}

Another way of restricting the exclusions to compulsory jurisdiction in section 3 is to reinterpret the meaning of the automatic limitations in Article 297. The chapeau of Article 297(1) provides that:

Disputes concerning the interpretation or application of this Convention with regard to the exercise by a coastal State of its sovereign rights or jurisdiction provided for in this Convention shall be subject to the proceedings provided for in section 2 in the following cases ....

This provision has long been understood as including an implicit 'only' and limiting the compulsory jurisdiction of Part XV courts and tribunals over disputes concerning the exercise by a coastal State of its sovereign rights and jurisdiction in the EEZ and on the continental shelf to the exhaustive list of subject matters in its subparagraphs (a) to (c). ${ }^{93}$ This understanding was also shared by the Tribunal in the Southern Bluefin Tuna Arbitration. ${ }^{94}$

The Tribunal in the Chagos MPA Arbitration adopted a new interpretation of Article 297(1). Based on a textual construction and an extensive review of the drafting history, ${ }^{95}$ the Tribunal held that Article 297, although captioned 'Limitations on applicability of

92 See ibid, paras 300, 302.

93 See eg R Churchill and V Lowe, The Law of the Sea (3rd edn, Juris Publishing 1999) 455; G Eiriksson, The International Tribunal for the Law of the Sea (Martinus Nijhoff Publishers 2000) 137-138; T Treves, 'The Jurisdiction of the International Tribunal for the Law of the Sea' in PC Rao and R Khan (eds), The International Tribunal for the Law of the Sea: Law and Practice (Springer 2001) 119; R Wolfrum, 'Das Streitbeilegungssystem des VN-Seerechtsübereinkommens' in W Graf Vitzthum (ed), Handbuch des Seerechts (CH Beck 2006) 472 MN 29; S Talmon, 'ITLOS - International Tribunal for the Law of the Sea' in H Volger (ed), A Concise Encyclopedia of the United Nations (2nd edn, Martinus Nijhoff Publishers 2010) 455; BA Oxman, 'Courts and Tribunals: The ICJ, ITLOS, and Arbitral Tribunals' in DR Rothwell et al. (eds), The Oxford Handbook of the Law of the Sea (OUP 2015) 404. This position was initially also taken by the Philippines in the South China Sea Arbitration but was later revised in light of the Award in the Chagos MPA Arbitration; see South China Sea Arbitration (Jurisdiction and Admissibility, Award of 29 October 2015) para 361.

94 Southern Bluefin Tuna (New Zealand-Japan, Australia-Japan) (Jurisdiction and Admissibility, Award of 4 August 2000) 23 RIAA 44, para 61: 'Paragraph 1 of Article 297 limits the application of such [compulsory dispute settlement] procedures to disputes concerning the exercise by a coastal State of its sovereign rights or jurisdiction in certain identified cases only, i.e. (a) cases involving rights of navigation, overflight, laying of submarine cables and pipelines or other internationally lawful uses of the sea associated therewith; and (b) cases involving the protection and preservation of the marine environment' (emphasis added).

95 See Chagos MPA Arbitration, Award, paras 307-317. 
section 2', was a 'jurisdiction-affirming provision' that did not include any limitation to the jurisdiction a Part XV court or tribunal may exercise. ${ }^{96}$ The Tribunal stated that:

Article 297(1) reaffirms a tribunal's jurisdiction over the enumerated cases ...; it does not restrict a tribunal from considering disputes concerning the exercise of sovereign rights and jurisdiction in other cases. Where a dispute concerns 'the interpretation or application' of the Convention, and provided that none of the express exceptions to jurisdiction set out in Article 297(2) and 297(3) are applicable, jurisdiction for the compulsory settlement of the dispute flows from Article 288(1). It is not necessary that the Parties' dispute also fall within one of the cases specified in Article 297(1). ${ }^{97}$

In case of disputes concerning the exercise by a coastal State of its sovereign rights or jurisdiction in the EEZ and on the continental shelf, the jurisdiction of Part XV courts and tribunals is thus not, or at least no longer, limited to disputes concerning 'the freedoms and rights of navigation, overflight or the laying of submarine cables' and to disputes concerning 'the protection and preservation of the marine environment'. Instead, it includes all disputes concerning the interpretation or application of the Convention, unless one of the limitations in Article 297(2) or 297(3) applies.

This opens up the possibility of Part XV courts and tribunals exercising jurisdiction over a wide range of disputes relating to the exercise by the coastal State of its sovereign rights or jurisdiction provided for in the Convention. For example, as a consequence of the Tribunal's new interpretation of Article 297(1), disputes concerning the exercise by a coastal State of sovereign rights over areas of the continental shelf beyond $200 \mathrm{~nm}$ (including disputes concerning the delineation of the outer continental shelf) may be brought before Part XV courts and tribunals. ${ }^{98}$ The jurisdiction of Part XV courts and tribunals also includes claims that the exercise of the rights of the coastal State over the continental shelf unjustifiably interfered with 'navigation and other rights and freedoms of other States', ${ }^{99}$ or that measures taken by a State within a safety zone around an artificial island to ensure the safety of the artificial island were not 'appropriate'. 100

\section{The Expansive Reading of Article 297(1)(c)}

Closely linked to the new interpretation of Article 297(1) as a 'jurisdiction-affirming', rather than a jurisdiction-limiting, provision is the expansive reading by the Tribunal in the Chagos MPA Arbitration of this jurisdiction-affirming provision. According to Article 297(1)(c), Part XV courts and tribunals have jurisdiction over:

96 ibid, paras 308, 315. This assessment was expressly shared by the two dissenting arbitrators; see ibid, Dissenting and Concurring Opinion, para 53. See also South China Sea Arbitration (Jurisdiction and Admissibility, Award of 29 October 2015) para 408(b). For a jurisdiction affirming rather than limiting reading of art 297(1), see also N Klein, Dispute Settlement in the UN Convention of the Law of the Sea (CUP 2005) 141; DR Rothwell and T Stephens, The International Law of the Sea (2nd edn, Hart Publishing 2016) 493.

97 Chagos MPA Arbitration, Award, para 317.

98 cfUNCLOS, art 297(2) and (3). Disputes concerning the interpretation or application of art 76 (7) and (8) also cannot be excluded by declaration; see UNCLOS, art 298(1)(a)(i).

99 See UNCLOS, art 78(2) (emphasis added).

100 See UNCLOS, art 60(4), cf also The Arctic Sunrise Arbitration (Netherlands $v$ Russian Federation) (Award on Jurisdiction, 26 November 2014) paras 68-78<http://www.pcacases. com/web/sendAttach/1325>. 
Disputes ... with regard to the exercise by a coastal State of its sovereign rights or jurisdiction provided for in this Convention ... when it is alleged that a coastal State has acted in contravention of specified international rules and standards for the protection and preservation of the marine environment ... which have been established by this Convention or through a competent international organization of diplomatic conference in accordance with this Convention. ${ }^{101}$

Article 297(1)(c) not only refers to specified rules and standards established through an international organization or diplomatic conference, but also to such rules and standards 'established by the Convention' itself. ${ }^{102}$ It affirms that Part XV courts and tribunals have jurisdiction under Article 288(1) over disputes concerning the violation of specific articles of the Convention, which, on their face, concern the protection and preservation of the marine environment. ${ }^{103}$

The minority went one step further. They found that 'Article 297(1)(c) has to be read together with Article 56(1)(b)(iii) and Part XII of the Convention [on the Protection and Preservation of the Marine Environment], which specifies the competences of the coastal State under that article'. ${ }^{104}$ Part XII does not provide a general competence for coastal States to issue rules on the protection and preservation of the marine environment. Therefore, the minority concluded that all cases where the coastal State allegedly exceeded its regulatory [or enforcement] powers under the Convention concerning the protection and preservation of the marine environment come under Article 297(1) (c). ${ }^{105}$ As a consequence, any claim that a coastal State exceeded its competence under the Convention when it established an MPA would be subject to the jurisdiction of Part XV courts and tribunals. ${ }^{106}$ The same would be true for a claim that a coastal State overreached its powers when regulating bunkering of ships in the EEZ. ${ }^{107}$ This interpretation makes Article 297(1)(c) a jurisdictional catch-all provision of the broadest scope that covers almost any dispute concerning the marine environment.

A further expansion of the jurisdiction of Part XV courts and tribunals was achieved by the Tribunal's finding that the reference to 'specified international rules and standards' in Article 297(1)(c) not only refers to substantive rules and standards but also includes procedural rules. The Tribunal held that 'the obligation to consult with and have regard for the rights of other States, set out in multiple provisions of the Convention, is precisely such a procedural rule and its alleged contravention is squarely within the

101 Emphasis added.

102 cf Chagos MPA Arbitration, Award, paras 319, 320; cf also ibid, Dissenting and Concurring Opinion, para 53.

103 cf Chagos MPA Arbitration, Award, para 318. UNCLOS arts 63 and 64 do not qualify as specified international rules and standards for the protection and preservation of the marine environment in terms of art 297(1)(c); see ibid, para 300.

104 Chagos MPA Arbitration, Dissenting and Concurring Opinion, para 52. This view is also shared by D Czybulka, 'Paradise lost? Die Entscheidung eines Internationalen Schiedsgerichts vom 18.3.2015 in Sachen Chagos Marine Protected Area (Republik Mauritius ./. Vereinigtes Königreich)' (2016) 14 Zeitschrift für Europäisches Umwelt- und Planungsrecht 72, who, however, regards art 56(1)(b)(iii) as a competency provision in its own right.

105 Chagos MPA Arbitration, Dissenting and Concurring Opinion, para 54.

106 cf ibid, para 55.

107 cf ibid, para 52, where the two dissenting arbitrators refer to the Joint Declaration of Judges Kelly and Attard in $M / V$ 'Virginia G' (Panama/Guinea-Bissau) (Judgment) ITLOS Reports 2014, 142 , who considered the regulation of bunkering as a measure for the protection and preservation of the marine environment. 
terms of Article 297(1)(c)'. ${ }^{108}$ Thus, disputes concerning violations of the procedural obligations to consult and balance in Article 194(1) and Article 194(4), respectively, come within the compulsory jurisdiction of Part XV court and tribunals. ${ }^{109}$ The same is true for disputes relating to the contravention of the duty in Article 206 to carry out an environmental impact assessment in advance of large-scale construction projects. ${ }^{110}$

\section{The Narrowing of the Exceptions in Article 297(3)(a)}

A further means to restrict the automatic limitations to compulsory jurisdiction in section 3 is to narrow the exceptions in Article 297(3)(a). The provision contains two parts. ${ }^{111}$ The first part affirms the compulsory jurisdiction of Part XV courts and tribunals with regard to 'fisheries' disputes in all maritime zones. The second part, which starts with the word 'except', expressly excludes from this jurisdiction:

[A]ny dispute relating to [a coastal State's] sovereign rights with respect to the living resources in the exclusive economic zone or their exercise, including its discretionary powers for determining the allowable catch, its harvesting capacity, the allocation of surpluses to other States and the terms and conditions established in its conservation and management laws and regulations. ${ }^{112}$

The exclusion extends to disputes concerning the rights of other States to fish in the EEZ. This is because the coastal State's sovereign rights with respect to the living resources in the EEZ and the fishing rights of other States there are 'intertwined'. ${ }^{113}$ The exclusion in Article 297(3)(a) also applies to procedural obligations of consultation and coordination. ${ }^{114}$

The Tribunal in the Chagos MPA Arbitration narrowed the exclusion in Article 297(3) (a) by strictly limiting its application to fisheries disputes concerning living resources in the EEZ. The provision thus does not apply to disputes concerning fishing rights of other States in the territorial sea. Furthermore, disputes concerning the conservation and optimum utilization of straddling fish stocks (Article 63) and highly migratory species (Article 64) are only excluded from the jurisdiction of Part XV courts and tribunals to the extent that they relate to the EEZ. If they concern measures beyond the EEZ, they are subject to compulsory jurisdiction. The Tribunal did not accept the argument that Article 297(3) should be construed narrowly in its application to straddling fish stocks and highly migratory species on the grounds that the entire purpose of the special regime for these species was to enable populations to be managed as a unified whole and that this object and purpose was potentially frustrated by providing distinct dispute settlement

108 Chagos MPA Arbitration, Award, para 322.

109 cf ibid, paras 302, 323(c), 539, 540.

110 cf ibid, para 322. In its Advisory Opinion of 1 February 2011, the ITLOS confirmed that 'the obligation to conduct an environmental impact assessment is a direct obligation under the Convention and a general obligation under customary international law'; see Responsibilities and Obligations of States Sponsoring Persons and Entities with Respect to Activities in the Area (Advisory Opinion) ITLOS Reports 2011, 50, para 145.

111 cf Chagos MPA Arbitration, Dissenting and Concurring Opinion, para 58.

112 Emphasis added.

113 Chagos MPA Arbitration, Award, paras 297, 300. Disputes concerning conventional or customary rights to fish in the EEZ fall under the exclusion in art 297(3)(a).

114 ibid, paras 300, 301. 
regimes for such species in the EEZ and in the high seas. ${ }^{115}$ The obligation to seek agreement upon the measures necessary for the conservation of straddling fish stocks set out in Article 63(2), which applies only to fish stocks in the high seas area adjacent to the EEZ of a coastal State, is thus not subject to the exclusion in Article 297(3)(a). The same is true for the obligation to cooperate with a view to ensuring conservation and promoting the objective of optimum utilization of highly migratory species beyond the EEZ as set out in Article 64(1).

In addition, disputes concerning the protection of coral in the EEZ are not excluded from compulsory jurisdiction by Article 297(3)(a) as coral is a sedentary species which is expressly excluded from the regime for the EEZ by Article 68 of the Convention. ${ }^{116}$

The minority further held that if the first part of Article 297(3)(a) - the affirmation of jurisdiction with regard to fisheries - 'is to retain some meaning, not all disputes on fisheries can be interpreted as "... any dispute relating to its sovereign rights with respect to living resources ...". The second part of the clause must be narrower in scope than the scope of the first part.' ${ }^{117}$ This must, generally, be correct. ${ }^{118}$ Correlating the exception in Article 297(3)(a) exclusively to disputes concerning the interpretation or application of Articles 61 and 62, as the minority seems to do, ${ }^{119}$ is, however, going too far. While it is correct that the second part of Article 297(3)(a) focuses on utilizing the living resources in the EEZ and their proper management and conservation, these are not the only sovereign rights a coastal State may exercise with respect to the living resources in its EEZ as is indicated by the use of the term 'including' in Article 297(3)(a).

\section{E. The a contrario Reading of Article 298(1)(a)(i)}

In practice, disputes concerning sovereignty or other rights over continental or insular land territory often arise incidentally to sea boundary delimitation disputes that concern the interpretation or application of Articles 15, 74 and 83. This does not, however, automatically make these land sovereignty disputes 'disputes concerning the interpretation or application of this Convention' within the compulsory jurisdiction of Part XV courts and tribunals. ${ }^{120}$ The Convention is silent on these so-called 'mixed disputes'. ${ }^{121}$

Article 298(1)(a)(i) allows States to exclude by declaration from compulsory jurisdiction 'disputes concerning the interpretation or application of Articles 15, 74 and 83 relating to sea boundary delimitations, or those involving historic bays or titles' that arose before the UNCLOS entered into force. If such disputes have arisen after the Convention entered into force they are subject to compulsory conciliation. But there is an exception to compulsory conciliation if such a dispute 'necessarily

115 ibid, para 301.

116 ibid, para 304.

117 Chagos MPA Arbitration, Dissenting and Concurring Opinion, para 58.

118 See also Nguyen (n 9) 139.

119 Chagos MPA Arbitration, Dissenting and Concurring Opinion, para 58.

120 cf IV Karaman, Dispute Resolution in the Law of the Sea (Brill 2012) 209 and n 212.

121 On 'mixed disputes', see generally I Buga, 'Territorial Sovereignty Issues in Maritime Disputes: A Jurisdictional Dilemma for Law of the Sea Tribunals' (2012) 27 International Journal of Marine and Coastal Law 59. 
involves the concurrent consideration of any unsettled dispute concerning sovereignty or other rights over continental or insular land territory'.

This provision has been read a contrario by some judges of the ITLOS, acting in a non-judicial capacity, and by a number of academic writers as meaning that in the absence of a declaration excluding maritime delimitation disputes from compulsory jurisdiction, unsettled disputes concerning territorial sovereignty are subject to the compulsory jurisdiction of Part XV courts and tribunals if they are closely linked or ancillary to a maritime delimitation dispute. ${ }^{122}$ The alternative reading of Article 298 (1)(a)(i) is that the provision merely clarifies that the general exclusion of territorial sovereignty disputes from compulsory dispute settlement also applies in the context of mandatory conciliation and that the clarification is needed because conciliation is a quite different form of dispute settlement that may well be broader than the jurisdiction of a court or tribunal under Part XV to make binding determinations. ${ }^{123}$

Neither the majority nor the minority expressly pronounced on 'mixed disputes'. The majority, however, stated that they were 'not convinced' by Mauritius' very broad $a$ contrario reading of Article 298(1)(a)(i) to the effect that land sovereignty disputes were generally subject to the compulsory jurisdiction of Part XV courts and tribunals when they formed a necessary part or had a genuine link to a dispute concerning the interpretation and application of any provision of the Convention. ${ }^{124}$ The majority stated:

Article 298(1)(a)(i) relates only to the application of the Convention to disputes involving maritime boundaries and historic titles. At most, an a contrario reading of the provision supports the proposition that an issue of land sovereignty might be within the jurisdiction of a Part XV court or tribunal if it were genuinely ancillary to a dispute over a maritime boundary or a claim of historic title. ${ }^{125}$

The majority did not categorically exclude a limited a contrario reading of Article 298(1) (a)(i), thus opening up the possibility of bringing at least some territorial sovereignty disputes before Part XV courts and tribunals. What the term 'genuinely ancillary' means in practice will have to be defined in future rulings of Part XV courts and tribunals, which gives rise to considerable uncertainty. ${ }^{126}$

122 See eg Statement by HE Judge Rüdiger Wolfrum, President of the International Tribunal for the Law of the Sea, to the Informal Meeting of Legal Advisers of Ministries of Foreign Affairs (New York, 23 October 2006) 6; Statement by Judge Albert Hoffman, Observer of the International Tribunal for the Law of the Sea, to the Asian-African Legal Consultative Organization (46th Session, Cape Town, 2-6 July 2007). The statements are reproduced in Chagos MPA Arbitration, Counter-Memorial Submitted by the United Kingdom, 15 July 2013, Annex 78 and Annex 81, respectively. See also T Treves, 'What have the United Nations Convention and the International Tribunal for the Law of the Sea to offer as regards Maritime Delimitation Disputes?' in R Lagoni and D Vignes (eds), Maritime Delimitation (Brill 2006) 77; PC Rao, 'Delimitation Disputes under the United Nations Convention on the Law of the Sea: Settlement Procedures' in TM Ndiaye and R Wolfrum (eds), Law of the Sea, Environmental Law and Settlement of Disputes: Liber Amicorum Judge Thomas A Mensah (Brill 2007) 896.

123 See Chagos MPA Arbitration, Hearing on Jurisdiction and the Merits, Final Transcript, 683: 14-19 (United Kingdom). See also S Talmon, 'The South China Sea Arbitration: Is There a Case to Answer?' in S Talmon and BB Jia (eds), The South China Sea Arbitration: A Chinese Perspective (Hart Publishing 2014) 46-47.

${ }_{124}$ Chagos MPA Arbitration, Award, para 218. 125 ibid.

126 On the uncertainties introduced by this terminology, see also the text at nn 49, 50 and 56 above. 
The minority was more sympathetic to a broad a contrario reading of Article 298(1)(a) (i). ${ }^{127}$ Although the two dissenting arbitrators did not expressly address the 'a contrario argument' they reached a result in line with that argument, namely that:

[A] dispute [concerning the interpretation or application of the Convention] which necessarily involves the concurrent consideration of an unsettled dispute concerning sovereignty or other rights over continental or insular land territory is not excluded from the jurisdiction of international courts or tribunals under Part XV by Article 298 of the Convention. ${ }^{128}$

While the Chagos MPA Arbitration has not exactly settled the controversy over mixed disputes, it provides some support for a limited a contrario reading of Article 298 allowing Part XV courts and tribunals to decide territorial sovereignty disputes ancillary to a maritime delimitation dispute or a dispute concerning historic bays or titles.

\section{CONCLUSION}

The Tribunal in the Chagos MPA Arbitration has contributed considerably to the expansion of compulsory jurisdiction of UNCLOS Part XV courts and tribunals by reading down the jurisdictional precondition to exchange views in Article 283(1); by broadening the meaning of 'any dispute concerning the interpretation or application of this Convention' to include incidental, related and - through the back door of a balancing exercise - even extraneous disputes; and by restricting the limitations and exceptions to compulsory jurisdiction in Articles 297 and 298. One of the most noteworthy 'inventions' of the Award is the majority's expansion, albeit incidentally, of compulsory jurisdiction to disputes concerning the interpretation and application of sources of law beyond the four corners of the Convention by balancing substantive rights originating in such sources with rights of a State under the Convention. ${ }^{129}$ Few would have predicted in 1982 that a Part XV court or tribunal would-within the context of such a balancing exercise-find that a colonial era undertaking created binding legal obligations under international law and that the United Kingdom was obliged 'to return the Chagos Archipelago to Mauritius when no longer needed for defence purposes'. ${ }^{130}$ This judicial finding may prove to be of considerable value to Mauritius if it demands the return of the Chagos Archipelago upon the expiration of the Agreement between the United Kingdom and the United States Concerning the Availability of Defence Purposes of the British Indian Ocean Territory on 20 December 2036. ${ }^{131}$

127 cf Chagos MPA Arbitration, Dissenting and Concurring Opinion, paras 26, 29-45.

128 ibid, para $38 . \quad 129$ See above section IIID.

130 Chagos MPA Arbitration, Award, para 547B(2).

131 See Exchange of Notes Constituting an Agreement between the Government of the United Kingdom of Great Britain and Northern Ireland and the Government of the United States of America Concerning the Availability for Defence Purposes of the British Indian Ocean Territory (London, 30 December 1966) 603 UNTS 273, para 11: 'The United States Government and the United Kingdom Government contemplate that the islands shall remain available to meet the possible defence needs of the two Governments for an indefinitely long period. Accordingly, after an initial period of 50 years this Agreement shall continue in force for a further period of twenty years unless, not more than two years before the end of the initial period, either Government shall have given notice of termination to the other, in which case this Agreement shall terminate two years from the date of such notice.' 
The Award in the Chagos MPA Arbitration is in line with the expansive reading of the jurisdictional provisions in Part XV by other Annex VII arbitral tribunals. For example, the Tribunal in the Guyana $v$ Suriname Arbitration held that 'it has jurisdiction to consider and rule on Guyana's allegation that Suriname has engaged in the unlawful use or threat of force contrary to the Convention, [Article 2(4) of] the UN Charter and general international law'. ${ }^{132}$ The ITLOS has also at times wandered beyond the Convention, such as when it effectively ruled on human rights issues in the Arctic Sunrise Arbitration. In that case the Tribunal decided that the Russian Federation must allow its own citizens to leave its territory, thereby giving effect to the right of persons to leave any country, including their own, as provided by Article 12(2) of the International Covenant on Civil and Political Rights and customary international law. ${ }^{133}$

The minority in the Chagos MPA Arbitration adopted an even more expansive approach to jurisdiction than the majority. By characterizing the long-standing sovereignty dispute between the parties as one concerning the interpretation of the term 'coastal State' for the purposes of the Convention, the minority found jurisdiction to rule that the detachment of the Chagos Archipelago from the colony of Mauritius 'was contrary to the legal principles of decolonization as referred to in UN General Assembly Resolution 1514 and/or contrary to the principle of selfdetermination', ${ }^{134}$ that any consent given to the detachment by Mauritian political leaders was 'invalid', ${ }^{135}$ and that the United Kingdom was not the 'coastal State' with regard to the Chagos Archipelago. ${ }^{136}$ Although not expressly pronouncing on the question of sovereignty, ${ }^{137}$ the minority incidentally decided that the United Kingdom was not sovereign over the Archipelago. The two dissenting arbitrators were sympathetic to the view that 'the words "coastal State" and the issues of sovereignty are interwoven in the present case'. ${ }^{138}$ They stated that:

[T]here are many situations referred to in the Convention in which, when it comes to a legal dispute, it is necessary to establish whether the State taking action is competent to do so. In many instances these disputes require a decision on the existence of competences or their scope and thus on the sovereignty of the State concerned ... It is to be noted that the issue of sovereignty will be a crucial factor in the reasoning [in the present case]. ${ }^{139}$

132 Maritime Delimitation (Guyana v Suriname) (Jurisdiction and Merits, Award of 17 September 2007) (2008) 47 ILM 239, para 487(ii). See also ibid, 201, para 261; and 227, para 423. This is a far cry, for example, from finding that a State 'used excessive force and endangered human life before and after boarding a ship'; see $M / V$ 'Saiga' (No 2) (Saint Vincent and the Grenadines $v$ Guinea) (Judgment) ITLOS Reports 1999, 63, para 159.

133 'Arctic Sunrise' (Kingdom of the Netherlands v Russian Federation) (Provisional Measures, Order of 22 November 2013) ITLOS Reports 2013, 250, para 95 and 252, para 105(1)(b); see also ibid, 289, para 46 (diss op Golitsyn). See also $M / V$ 'Louisa' (Saint Vincent and the Grenadines $v$ Kingdom of Spain) (Judgment) ITLOS Reports 2013, 46, paras 154-155. See further ibid, 41-42, para $131 ; 43$, para, 139; 44, para 141; and 155, paras 68, 69 (diss op Jesus); 165, para 42 and 168, para 55 (diss op Lucky).

${ }_{134}$ Chagos MPA Arbitration, Dissenting and Concurring Opinion, para 70; see also ibid, paras $71-73$.

135 ibid, para 78 and paras $74-77$.

136 ibid, para 80. For criticism of these findings by the minority, see Czybulka (n 104) 70-71.

137 Chagos MPA Arbitration, Dissenting and Concurring Opinion, para 17.

138 ibid, para $8 . \quad 139$ ibid, para 42 (emphasis added). 
Considering the narrow majority by which the question of the character of the dispute was decided in the Chagos MPA Arbitration and the strong views held by the two dissenting arbitrators, it cannot be ruled out that, in the future, Part XV courts or tribunals of a different composition may characterize disputes concerning sovereignty over continental and insular land territory as disputes concerning the interpretation or application of the term 'coastal State' for the purposes of the Convention. ${ }^{140}$ This would mean that any sovereignty dispute involving some territory with a coastline could be presented as a claim under UNCLOS Part XV whenever the coastal State exercised some right falling within one of the numerous Articles of the Convention that establish the rights of the coastal State. This would make Part XV courts and tribunals the international forum of choice for countless territorial sovereignty disputes. ${ }^{141}$

Such expansive reading of the jurisdictional provisions of Part XV raises questions about the competence of UNCLOS Annex VII arbitral tribunals. Arbitrators must be persons 'experienced in maritime affairs and enjoying the highest reputation for fairness, competence and integrity'. ${ }^{142}$ They need not necessarily be qualified for judicial office or be persons of recognized competence in general international law. ${ }^{143}$ Indeed, they do not even have to be lawyers or be legally trained. This may result in a 'competency gap' between the arbitrators' actual competency level and that required to decide complex and complicated questions of general international law. ${ }^{144}$ A lack of expertise beyond the narrow confines of the law of the sea may affect the quality of and undermine compliance with awards by Annex VII tribunals on questions of selfdetermination, human rights, the threat or use of force, or territorial sovereignty. If the creeping expansion of jurisdiction of UNCLOS Part XV courts and tribunals continues, a high level of knowledge of public international law should be taken as an implicit requirement for any person appointed to the list of arbitrators under Article 2 of Annex VII of UNCLOS.

The Chagos MPA Arbitration is an excellent example of the creative or strategic use of the UNCLOS compulsory dispute settlement mechanism in order to gain a ruling on issues that have nothing to do with the law of the sea. ${ }^{145}$ Alan Boyle pointedly noted that 'everything turns in practice not on what each case involves but on how the issues are formulated'. ${ }^{146}$ If the Chagos MPA Arbitration sets a precedent it will not

${ }^{140}$ For the view that the question of jurisdiction over territorial sovereignty disputes has not yet been fully settled, see also Colson and Vohrer (n 9) 851; Nguyen (n 9) 130.

141 Possible territorial sovereignty disputes that could thus be brought before Part XV courts and tribunals include the Diaoyu/Senkaku islands, the Falkland Islands, South Georgia and the South Sandwich Islands, parts of Antarctica, Dokdo/Takeshima, the Spratlys, Paracels or other features in the South China Sea, Belize, Sabah, Tromelin, the Hala'b Triangle, Abu Musa, Western Sahara, Mbanie Island, Mayotte, Perejil Island; see Chagos MPA Arbitration, Counter-Memorial Submitted by the United Kingdom, 15 July 2013, para 4.61; ibid, Rejoinder Submitted by the United Kingdom, 17 March 2014, para 4.12, n. 356; and ibid, Hearing on Jurisdiction and the Merits, Final Transcript, 673: 18 (United Kingdom).

142 UNCLOS Annex VII, art 2(1).

143 cf Statute of the ICJ, art 2.

144 For the lack of expertise in general international law of judges on the European Court of Human Rights and ensuing problems, see D Kosař, 'Selecting Strasbourg Judges: A Critique' in M Bobek (ed), Selecting Europe's Judges: A Critical Review of the Appointment Procedures to the European Courts (OUP 2015) 147-9. 145 cf Colson and Vohrer (n 9) 845.

146 AE Boyle, 'Dispute Settlement and the Law of the Sea Convention: Problems of Fragmentation and Jurisdiction’ (1997) 46 ICLQ 44-5. 
be long before protracted conflicts resulting, for example, from the occupation of northern Cyprus, the forcible separation of Abkhazia from Georgia or the annexation of Crimea will somehow be shoehorned into the framework of UNCLOS Part XV. ${ }^{147}$ Part XV courts and tribunals faced with attempts to stretch the scope of compulsory subject-matter jurisdiction under UNCLOS ever further should tread carefully when interpreting and applying the jurisdictional provisions in Part XV. The significance for States of the limits to compulsory jurisdiction consciously built into the Convention should not be underestimated. ${ }^{148}$ Any finding that a Part XV court or tribunal has jurisdiction to rule, albeit incidentally, on questions of territorial sovereignty, selfdetermination or human rights could have far-reaching implications for the universality of UNCLOS both in terms of future accessions to and, indeed, potential denunciations of the Convention.

147 Thus it has been reported that Ukraine is preparing a 'UNCLOS case' against the Russian Federation with regard to the Russian annexation of Crimea; see eg 'Kyiv ready to file claim against Russia's violation of UN convention on law of sea, no political decision of authorities' (Interfax Ukraine, 29 January 2016) <http://en.interfax.com/>.

148 cf Chagos MPA Arbitration, Hearing on Jurisdiction and the Merits, Final Transcript, 44: 4-16, 646: 21-4, 647: 1-2, 6-9, 648: 9-13 (United Kingdom). 